\title{
Ritual and Family: Preparation for First Communion in Pamiętaj abyś dzień święty święcit (Remember to Keep Holy the Lord's Day) by Maciej Cuske and Komunia (Communion) by Anna Zamecka
}

\author{
Piotr Zwierzchowski iDhttps://orcid.org/0000-0002-1770-777X \\ Kazimierz Wielki University in Bydgoszcz \\ piotr.zwierzchowski@ukw.edu.pl
}

\begin{abstract}
The present paper discusses two Polish film documentaries taking up the subject of First Communion: Pamiętaj abyś dzień święty święcit (Remember to Keep Holy the Lord's Day, 2008) by Maciej Cuske, and Komunia (Communion, 2016) by Anna Zamecka. Both films reflect on contemporary Polish religiosity and on the social functioning and perception of the sacrament and ritual of First Communion. They also address the issues of the social and mental maturity of the child receiving the sacrament, and the ceremony's significance for the life of the family. The paper analyses and interprets the films as the directors' personal commentaries, as chronicles of individual stories, and as attempts at social diagnoses.
\end{abstract}

Keywords: Polish cinema, documentary films, Polish customs, First Communion, contemporary Polish religiosity

Słowa kluczowe: kino polskie, kino dokumentalne, obyczaje polskie, pierwsza komunia święta, współczesna religijność Polaków

First Communion is deeply entrenched in Polish sociocultural reality, and it seems entirely natural that it should be depicted in feature and documentary films. However, it is usually treated either as one of the many threads or elements of the depicted universe, or as a simple illustration of native customs. For that reason, Maciej Cuske's Pamiętaj abyś dzień święty święcit (2008) and Anna Zamecka's Komunia (2016) attract special attention. In both films - both awarded prizes at multiple festivals, 
including internationally - First Communion is a dominant theme. However, although the sacrament itself is very important for the protagonists, it does not hold central position in the films' structures, serving as a medium conveying other meanings. ${ }^{1}$ What connects the two films is how they focus mostly on the preparation for First Communion. Cuske and Zamecka, having no aspirations to tackle the topic from the perspective of theology or study of religions, mainly consider the social meanings of the sacrament and ritual of First Communion, including the role of the family and the relation between a child's religiosity and its social and mental world. These are the topics I will consider by drawing attention to the poetics of both films, and by treating them as the directors' different yet similar personal commentaries, chronicles of individual stories, and attempts at a social diagnosis.

In Komunia, Ola prepares her younger brother, thirteen-year-old Nikodem, for First Communion. Nikodem, who suffers from autism, had not been allowed to receive the sacrament earlier - the priest felt that the boy was not sufficiently prepared in spiritual terms. It was Zamecka who persuaded the family that Nikodem should try once again. The task was not easy and a visit to another parish was necessary to obtain the rector's consent. "Preparations for a family celebration became a dramaturgical axis of the film," 2 and Ola became its pivotal character, as it was her involvement that made the entire pursuit possible. In this family, the parents did not support their children - the mother left them when the siblings were still very young, and the father could not cope.

Maciej Cuske's film is an autobiographical documentary. The director tells the story of himself, his own family, and - first of all - of his son Staś, who is about to receive his First Communion. Although Cuske combines autoethnography with sociological observations, his focus is not on his personal tale, but on more general questions. Still, the fact that he depicts his own family makes his considerations truer and more convincing. Besides, Pamiętaj abyś dzień święty święcit is not so much about Staś' religiosity as it is about that of his parents, and their "intimate corners of conscience." $" 3$

Cuske's and Zamecka's films, the latter perhaps even more so, illustrate encounters between a child's social world and religion. For both Staś and Nikodem, religious matters are far removed from their own experience and understanding of the world. In both films, an important question is posed: how can one introduce and convey the realm of spirituality to a child? Neither Cuske nor Zamecka answer this question.

${ }^{1}$ Zamecka expresses this idea directly: "In my film, Communion acts, above all, as a metaphor. It is a pretext to tell the story of Ola, the protagonist, of her situation and the process of maturation." Anna Zamecka: Temat „dorostych dzieci” jest tabu. Rozmawiamy z reżyserka najgłośniejszego polskiego dokumentu tego roku, rozm. Ł. Knap, https://film.wp.pl/anna-zamecka-temat-doroslych-dzieci-jest-tabu-rozmawiamy-z-rezyserka-najglosniejszego-polskiego-dokumentu-tego-roku-6184908614125697a [access: 6 września 2018].

${ }^{2}$ Komunia jako metafora wkroczenia w dorostość. Z Anna Zamecka, reżyserka filmu „, Komunia”, “Magazyn Filmowy SFP” 2016, no. 11, p. 46.

${ }^{3}$ M. Piepiórka, Maska i demistyfikacja. Wątki autobiograficzne we wspótczesnych polskich filmach dokumentalnych, "Panoptikum" 2013, no. 12, p. 94. 
However, they express many doubts related to the issue. These are particularly important in the case of Nikodem, due to not only the boy's age but also his autism.

Cuske manages to convey these doubts through the film's composition and through cinematic means of expression. The opening shot, showing Staś cycling along a path through green meadows, is already significant. The idyllic atmosphere of the scene alludes to the small boy's innocence. Immediately after the opening credits, we are transported first to the interior of the church where Staś and his friends take part in the service, and then to the family home, where we listen to conversations about preparations for First Communion. In the closing shot, Staś, now older, is amidst the grass again, riding a bike - this time the one he received as a Communion gift. Has anything changed? It is just about the gift? Or did the preparations and the sacrament itself affect the spirituality or religiosity of Staś in some way? If so, did the family or the Church have more influence? Cuske leaves these questions unanswered, letting the viewer arrive at their own conclusions.

In Pamiętaj abyś dzień święty święcit, the differences between the scenes at home and at the church are as striking as they are important. In the former, we observe Staś talking to his parents and grandparents, sometimes jokingly and at other times seriously, while the adults, coming to terms with their own attitudes and doubts related to religion, try not only to prepare the boy for his First Communion, but also to convey to him the idea of faith. They treat him seriously, but take into account his perceptual, linguistic, and imaginative abilities, to avoid introducing confusion into the child's world.

The scenes shot at the church are fewer, which is part of the film's design, reflecting its meaning. The church is not a natural environment for Staś and his friends. The boy behaves much more freely at home - a fact that also illustrates the difference between sacred and profane space. What matters more, however, is that at the church Staś only learns ritual gestures, words, and songs, as if he was preparing for some kind of performance. It is at home that he undergoes true religious education. Attending mass and church meetings bores and even discourages him. At one point his parents wonder if "his energy should be restored with a bicycle."

Although irony is not lacking from the film, it is absent from Cuske's depiction of the very celebration of First Communion. The director presents an honest picture of the children, who act appropriately for their age. They are emotional, as they know something important is happening. Dressed elegantly, they smile, they get serious, but then they cannot help fidgeting and yawning. Receiving the Eucharist for the first time is experienced as a ritual, but it is difficult to interpret it in terms of spirituality. Did the ceremony affect Staś' religiosity? A few years after the film was made, Maciej Cuske recalls that his son, "tired of the Communion ceremony, became a little fed up with the church, and stopped going for some time. But then he came back and, surprisingly, told me one day that he became an altar boy. He has periods of doubt, just like me."

${ }^{4}$ A. Szyłło, Staś przystapit, "Gazeta Wyborcza” 2004, 8 maja, http://wyborcza.pl/duzyformat/1,127 290,15917294,Stas_przystapil.html [access: 23 June 2018]. 
Notable is the way the very moment of receiving the Eucharist is depicted. Cuske shows neither Staś nor any of his female and male friends. The camera watches the children closely as they approach the altar, kneel, fold their hands and - that's it. At the decisive moment, someone suddenly enters the frame. Of course, Cuske is too experienced a documentarian for this to be an accident. He halts on purpose, to avoid penetrating the mysteries of faith. Anna Zamecka does the very same. In Komunia, the church scenes during the First Communion ceremony are even shorter and neither do they show the reception of the sacrament. As I have mentioned, both filmmakers concentrate on the social and psychological meanings of the sacrament and ritual of First Communion, and, even more so, of the preparations for it. At the same time, these themes become a handy medium for undertaking other related problems.

In Komunia, preparations for the sacrament turn into a school ritual, during which truths of faith are stripped of their spiritual dimension. The infantilizing religion lessons, with their games used to attract the pupils' attention, are criticized for reducing faith to ordinary school activities, thus depriving it of mysticism. During the prayer at the beginning of the lesson, the pupils act frivolously, just as children in a classroom would. Although at one point the priest contrasts the behaviour at school with that at the church, the earlier scenes in the classroom do not seem to support this distinction. When at one point Nikodem announces at the church that "Jesus rules," we could attribute his behaviour to his condition. What his exclamation really reflects, however, are the customs typical for school youth.

Despite the above, Zamecka's intention is to make simple observations concerning the presence of religion at school or the ways religion is taught. Komunia exposes certain ambivalence, amplified by Nikodem's disability. It makes the viewer concerned about the boy's ability to participate in religious rites and education. The boy's behaviour often confirms this concern. Nikodem has a separate notebook for religion lessons, but it is difficult to regard the notes he takes as part of religious education. The sentences he writes include: "We don't want Douns ${ }^{5}$ [sic] here," "Douns not allowed," "Life is a rat," "He was born to be a rat," "When Jesus was born, dinosaurs..." Unsurprisingly, a nun pulls the problematic sheet of paper out of the boy's notebook. However, although Nikodem's slogans have nothing to do with the boy's religious knowledge or his First Communion, they reflect his social exclusion.

However inaccessible Nikodem's world of religious imagination might be, Котиnia still gives us a peek into how it is built. One scene where the boy has a conversation with the priest about virtues is a good illustration of the process. Earlier, Ola had bombarded Nikodem with questions: "What does it mean to believe? What is virtue? Which virtues are most important? What are God's commandments? Which of God's commandments is most important? Who is the Pope? Who are the priests?" When Nikodem answers these questions before the priest, he demands to have them asked in appropriate order, because he has learnt the answers by heart. He has an excellent memory, but any change in sequence would cause confusion. The obvious conclusion is that there is no reflection in Nikodem's learning process. However, by wishing for the boy to succeed, we begin to wonder not only about his situation, but also about

5 "Doun" is a misspelled derogatory expression referring to people with Down's syndrome. 
that of other children preparing for the sacrament. Pamiętaj abyś dzień święty święcit, and the story of Staś make us wonder even more.

Both films are attempting to depict the development of a child's awareness. A child becomes familiar with a ritual by adjusting it to their system of values and cognitive abilities. Staś, like the other children, obviously thinks about the gifts he will receive, but his conversations with his parents do not lack important reflections and questions. When asked if he believes in God, he replies that he does, one hundred per cent. However, he has a problem with the miracles, as he cannot understand their meaning. $\mathrm{He}$ asks his parents a similar question (by replying that they once believed one hundred per cent, they both show, to some extent, their current distance from the faith). However, we do not learn much about Staś' religious emotions and experiences. It is difficult to get a sense of the boy's spirituality, or his actual familiarity with the values of faith. This obscurity has to do with the boy's age, but also is a part of the film's concept.

Nikodem is unable to remember many abstract concepts, but this does not mean that he does not try to reflect upon them within the limits of his age and disability. Calling this a spiritual search would be an overstatement. Still, by showing how a child with Nikodem's disability makes sense of the world, Zamecka is able to show the less obvious ways of understanding the rules of faith. An interesting example is found in a scene of preparation for confession, when the priest asks Nikodem about his sins. He adjusts his question to the boy's age, but the outcome is unexpected. "But gluttony isn't a sin to me, it's a virtue to me," objects Nikodem when he hears about the seven deadly sins. His also objects when the priest mentions three divine virtues: faith, hope, and love. According to the boy, love is a sin "because they kiss each other." This individual search for meaning in the context of religion moved the director:

The priest refused the sacrament to the boy, recognizing him as spiritually unprepared. The family was hurt by this decision.

Once, I went with Nikodem to a religion lesson. The catechist asked the children to takedown the Decalogue written on the board. Nikodem wrote his own commandments, very poetic and personal, for instance: "Feed me," "Save me," "Be caring." I thought that if this boy is not "spiritual" enough, then who is. ${ }^{6}$

According to Zamecka, it is wrong to worry about a disabled child's inability to prepare for First Communion. Finding a family catechist and considering what is possible to achieve within the set limits can make the preparations successful. ${ }^{7}$ This is actually what happens in the documentary. Nikodem finally receives the communion after many unexpected hardships. But, eventually, it is not his parents who contribute to his success.

${ }^{6}$ M. Karst-Adamczyk, Nagroda Europejskiej Akademii Filmowej dla „Komunii” Anny Zameckiej. Reżyserka: Opowiedziałam o rzeczach, które były dla mnie ważne, "Gazeta Wyborcza. Wysokie Obcasy" 2016, no. 48, http://www.wysokieobcasy.pl/wysokie-obcasy/7,127763,21019101,anna-zamecka-rezyserka-filmu-komunia-rodzina-jest-dla.html [access: 23 June 2018].

${ }^{7}$ Rev. A. Kiciński, Katecheza przed I komunia święta dziecka z niepetnosprawnościa intelektualna. Studium przypadku, https://opoka.org.pl/biblioteka/T/TA/TAK/ak_katecheza_niepelnosp.html [access: 5 September 2018]. 
Although the priest emphasizes that the parents are responsible for a child's religious education - a similar attitude is expressed in Pamiętaj abyś dzień święty święcit - it is Ola who cares for Nikodem in this regard. She is unprepared for this role, but she takes over nonetheless. Preparing her brother for First Communion becomes her own rite of passage, one leading her to maturity. She lives in a broken family, burdened by her father's helplessness and passivity towards everyday life matters. She talks to her mother only on the phone. She sees the ceremony as a chance for her parents to meet, and for her mother to reunite with them. However, she must ultimately face the bitterness of this plan's failure.

Ola believes that, in spite of so many obstacles, it is possible for her family to live together. Only gradually does she begin to accept that this will never happen - it is, among other things, what her maturation consists of. Communion understood as the uniting of loved ones into an ideal community turns out to be an illusion. ${ }^{8}$

In Pamiętaj abyś dzień święty świecit, the situation is different. The key to comparing these films is largely the contrast between the two types of families. To some extent, this contrast is already expressed in how the films differ in composition and structure. Cuske ends his film with Staś receiving his First Communion, and the party that follows, to which guests are invited. In Zamecka's film, First Communion opens the second part of the narrative, where the story of family relations, and the failed attempt to bring the mother back home, come to the fore.

In the scenes of the boys preparing for their exams, we see two strategies of their tutors. Ola threatens her brother with the priest-examiner and with their father's punishment, and she scolds the boy, as she is not able to cope with the task. We watch the siblings struggle with the impossible, and witness the sister's drama of helplessness and loneliness. Staś' parents are also catechizing their son, but in face of the difficulty of the task, they resort to the comforting atmosphere of an evening family gathering. The mood of that scene is warm and cheerful - we see a family community.

Staś receives his First Communion, thus confirming his entry into the tradition of family rituals. It is a feast, especially for his grandparents. The parents express their distance towards this form of religiosity, but nevertheless, when they talk about their memories, matters of faith and religion are inseparable from their childhood as a whole. They also create conditions for their son to participate in and experience this traditional ritual in the best possible way.

Pamiętaj abyś dzień święty święcit shows First Communion as a private feast of a three-generation family. Cuske paints an image of the oldest generation's concern about consolidating the religious tradition. He refers to his own experiences. One of the reasons why he and his wife decided to follow through with their son's First Communion were the expectations of the director's parents. What mattered was not only the sacrament itself, but also the rituals related to it. At the same time, generational differences surface, as well as different attitudes to religion and its presence in everyday life. Cuske's family has a strong emotional bond, palpable in everyday

${ }^{8}$ Anna Zamecka: Temat ,,dorostych dzieci” jest tabu..., op. cit. 
life, even though they are divided by their attitudes towards religion. ${ }^{9}$ The film also proves - as writes Tadeusz Lubelski - "that religious rituals are a testimony of collective hypocrisy in our families [...]." ${ }^{10}$ For Staś' grandparents, First Communion, celebrated according to custom, is not only a natural part of everyday existence but also a necessary condition of adapting to social life.

According to Michał Piepiórka, Maciej Cuske "touches an extremely intimate sphere of religiosity- his reflections revolve around psychological and emotional issues more than around the problems of the outside world." 11 However, it is difficult to agree with this statement. The rules of the outside world largely dictate the need for the boy to receive First Communion. His grandfather expresses this idea directly: Staś must receive the sacrament, because he lives in a Catholic state and will not be able to cope later on. Also of great relevance in this context are the conversations about politics, especially about the elections and public behaviour after the death of John Paul II. These are included not only to identify the views of particular members of the family, but also to realize all the contexts. First Communion is not a phenomenon separated from social life. For example, it is impossible not to notice the link between the grandparents' religiosity and their perception of Polishness.

Both films also carry yet another message. Even if doubts are expressed related to faith, concentration on social rituals, and generational differences in experiencing and understanding religiosity, in both cases First Communion is depicted as something that gives meaning to family life, regardless of how the event is perceived by family members. In Pamiętaj abyś dzień święty święcit this message is more pronounced, but it is mainly due to the character of the family itself. All the family members support Staś, although each of them does it in a different way. In Komunia we are dealing with a dysfunctional family. This does not mean, however, that there is no love between its members, even if expressed with more difficulty. Ultimately, Nikodem receives his First Communion, achieving the seemingly impossible, and thus denying his exclusion. The feast is primarily for his sister.

In Zamecka's film, the ceremony itself doesn't seem to change the family. The mother returns for a moment, appears at the ceremony, comes to dinner. However, is not a dinner eaten together, but ingested hurriedly at the same table. The mother cannot bear living with her family - after all, she did not leave in the first place without a reason. However, observing the father, Ola and Nikodem, one has no doubts that, despite the harshness of their relationship, they have succeeded in surviving and experiencing this day. Zamecka filmed the very ceremony depicting not only Nikodem, ceremonially dressed and sitting on a bench, but also the happy Ola and their parents. The girl is seated between her mother and father, separating them despite their apparent togetherness. At the moment, however, this separation does not matter. For this one moment they are a community, in spite of everything, at least in the eyes of

${ }^{9}$ M. Przylipiak, Kino Paladino, albo schytek wielkich narracji, [in:] Zobaczyć siebie. Polski film dokumentalny przełomu wieków, M. Jazdon, K. Mąka-Malatyńska (eds.), Poznań 2011, p. 46.

10 T. Lubelski, Historia kina polskiego 1895-2014, Kraków 2015, p. 676.

${ }^{11}$ M. Piepiórka, op. cit., p. 93. 
the girl. After all, there's a reason why in the Polish tradition First Communion is so strongly connected to the notion of family.

Nowadays holiness, or rather "ceremonialism," enters homes along with the customs related to the reception of First Communion. Here too one can talk about the sacred, but at a different level. It is the family that becomes the dominion of holiness and ceremonialism. Thus, a family meeting is an opportunity to get to know its members and to form the collective form of the family. Currently, attention is drawn to the fact that home parties, costumes and gifts take over the entire prestige of the ceremony, while the church ceremony is increasingly seen only as an empty ritual. ${ }^{12}$

In Polish society and culture, First Communion celebrations, although they have evolved, have retained their prestige among family and social celebrations. ${ }^{13}$ Next to weddings, they belong to "the most festive events in human life [...] - customs associated with these rituals receive the most media coverage." ${ }^{\prime 4}$ Every year dozens of texts are published in the printed press and on on-line forums, concerned with communion customs, especially the increasingly lavish parties and gifts. Authors point to the phenomenon of social desacralization, but more often they focus on advice regarding dress, gifts, and party planning. They do not attempt to draw the reader's attention to the spiritual side of the sacrament. This is also the case with popular TV series, especially family sagas. ${ }^{15}$ Even if some articles do contain critical remarks about dominant attitudes and behaviours, they also contribute to the commercialization of the event, promoting secular customs developed along with increasingly consumerist attitudes.

The title of Maciej Cuske's film is quite ironic in this context. We obviously remember to keep the God's day holy, but First Communion is becoming more a part of the secular order than of God's one. This is also how the ceremony, the church, and the presence of the priests are perceived. All the activities are seen as part of a ritual upon whose sense hardly anyone reflects. Of course, this might be a far-reaching generalization, but it is proved in everyday life and media coverage.

Cuske's film makes us realize, perhaps accidentally, something we encounter so often that we have come to take it for granted. Filming family and church celebrations has already entered the canon of social behaviour. The crowd of people with cameras present at the celebration illustrates this fact, as well as the director's own decision to film Staś, himself, his wife and parents on this occasion. In Pamiętaj abyś dzień święty święcit and Komunia photographs and films are a compulsory part of a family tradition and, at the same time, of cultural reproduction, regardless of the state of one's faith and religious awareness.

Both films are a testament to the power of custom. This power is manifest in the way the ceremony is justified, during the preparation phase, during the ceremony

12 R. Miciński, Granice sacrum w rytuale pierwszej komunii świętej, "Pracownia Kultury" 2011, no. 1, http://www.laboratoriumkultury.us.edu.pl/?p=3735 [access: 18 July 2018].

13 T. Czekalski, Czasy wspótczesne, [in:] Obyczaje w Polsce. Od średniowiecza do czasów wspótczesnych, A. Chwalba (ed.), Warszawa 2008, p. 384.

14 B. Łaciak, Obyczajowość polska czasu transformacji, czyli wojna postu z karnawałem, Warszawa 2007, p. 286.

15 Ibidem, pp. 287-291. 
itself and during the activities that follow. A striking example in Pamiętaj abyś dzień święty święcit is that of Staś' mother returning from the hairdresser with a mass of curls on her head. This image exposes the ritualization of the need for proper preparation for a festive occasion. Paradoxically, the self-deprecating remarks of a woman ridiculing her own looks emphasize the power of custom. For Cuske, this secular encasement provides an extremely important context. In his observation, the sacrament means "many beads that must be strung side by side: the suit, the hairstyle, the rosary, the catechism, the shoes, the party, the photos, the video"; ${ }^{16}$ and, in addition to all this, the rehearsals, the preparations, the selection of clothes, and, finally, the gifts. This observation influences his attitude towards the way the First Communion ceremony is organized and experienced, perhaps more so by adults than by children.

I'm not an atheist. I don't profess any other faith. I'm more of a believer, though sometimes, and maybe even often - a doubter. Essentially, I'm not an enemy of this ceremony, though I'm sceptical and somewhat sarcastic about the form this ritual takes in such typical Polish parishes as ours, in Bydgoszcz. ${ }^{17}$

Pamiętaj abyś dzień święty święcit is part of the 2008 Decalogue series that - as Marek Lis writes - "records people who struggle with their own doubts and (un)faith." 18 Mirosław Przylipiak perceived Cuske's film similarly, although somewhat differently, noting that it "documents the phenomenon of erosion of one of the strongest bonds of the Polish society - the Catholic religion which is felt less and less is in every subsequent generation. At the same time the erosion of national or state ties is also shown." 19

In Komunia, critical observations concerning the social functioning of religion are also easy to note. Both films, without delving into the religious meaning of First Communion, depict the difficulty, and sometimes the incompatibility, of faith with the cognitive abilities of a child, also an autistic one. They pay attention to the contradiction between communion as accession, and the social exclusion it entails. They depict social desacralization of the celebrations related to the reception of First Communion. Despite all this, both Cuske's and Zamecka's films can be defined, paradoxically, as optimistic. The strength of intra-family relationships, even despite the departure of Ola and Nikodem's mother and the girl's ensuing bitterness, is undeniable. In both Pamiętaj abyś dzień święty święcit and Komunia, a true community is formed through the relationship between the ceremony and ritual, and the family life.

As I have already suggested, neither Maciej Cuske nor Anna Zamecka comments on the significance of First Communion from the perspective of theology or study of religions. In fact, they do not intend to. Their films can be looked at as personal commentaries, individual forms of expression - similar and different at the same time - and as portraits of children receiving their First Communion and of their

\footnotetext{
${ }_{16}$ A. Szyłło, op. cit.

17 Ibidem.

${ }^{18}$ M. Lis, Przed i po Dekalogu. Spojrzenia na polska religijność, [in:] Zobaczyć siebie..., op. cit.,

${ }^{19}$ M. Przylipiak, op. cit., pp. 45-46.
} p. 59. 
families. They are both also generalizing enough to pose questions about contemporary Polish religiosity ${ }^{20}$ - or rather religiosities. The directors are especially interested in the social reception and functioning of the sacrament and ritual. They also both take up the issue of the social and mental maturity of the child receiving First Communion, and of the doubts surrounding it. Cuske and Zamecka also consider the significance of First Communion for family life, and evaluate it very highly. The value of Pamiętaj abyś dzień święty święcit and Komunia lies in their numerous interesting observations supported by the credibility of the narratives, as well as in the one-of-akind positive agendas of both directors.

\section{Translated by Witold Brzeziński}

\section{References}

Anna Zamecka: Temat „,dorostych dzieci” jest tabu. Rozmawiamy z reżyserka najgłośniejszego polskiego dokumentu tego roku, rozmawiał Ł. Knap, https://film.wp.pl/anna-zamecka-temat-doroslych-dzieci-jest-tabu-rozmawiamy-z-rezyserka-najglosniejszego-polskiego-dokumentu-tego-roku-6184908614125697a [access: 6.09.2018].

Czekalski T., Czasy współczesne, [in:] Obyczaje w Polsce. Od średniowiecza do czasów wspótczesnych, A. Chwalba (ed.), Warszawa 2008, pp. 339-426.

Karst-Adamczyk M., Nagroda Europejskiej Akademii Filmowej dla „, Komunii” Anny Zameckiej. Reżyserka: Opowiedziałam o rzeczach, które były dla mnie ważne, "Gazeta Wyborcza. Wysokie Obcasy” 2016, no. 48, http://www.wysokieobcasy.pl/wysokie-obcasy/7,127763,21019101,anna-zamecka-rezyserka-filmu-komunia-rodzina-jest-dla.html [access: 23.06.2018].

Kiciński A., Katecheza przed I komuniq święta dziecka z niepetnosprawnościa intelektualną. Studium przypadku, https://opoka.org.pl/biblioteka/T/TA/TAK/ak_katecheza_niepelnosp.html [access: 05.09.2018].

Komunia jako metafora wkroczenia $w$ dorostość. Z Anna Zamecka, reżyserka filmu „,Komunia”, "Magazyn Filmowy SFP" 2016, no. 11, p. 46.

Lis M., Przed i po Dekalogu. Spojrzenia na polska religijność, [in:] Zobaczyć siebie. Polski film dokumentalny przełomu wieków, M. Jazdon, K. Mąka-Malatyńska (eds.), Poznań 2011, pp. 51-60.

Lubelski T., Historia kina polskiego 1895-2014, Kraków 2015.

Łaciak B., Obyczajowość polska czasu transformacji, czyli wojna postu z karnawałem, Warszawa 2007.

Mąka-Malatyńska K., Dokumentalny autobiografizm, [in:] Historia polskiego filmu dokumentalnego (1945-2014), M. Hendrykowska (ed.), Poznań 2015, pp. 599-606.

Miciński R., Granice sacrum w rytuale pierwszej komunii świętej, "Pracownia Kultury" 2011, no. 1, http://www.laboratoriumkultury.us.edu.pl/?p=3735 [access: 18.07.2018].

Piepiórka M., Maska i demistyfikacja. Wątki autobiograficzne we współczesnych polskich filmach dokumentalnych, "Panoptikum" 2013, no. 12, pp. 88-101.

Przylipiak M., Kino Paladino, albo schyłek wielkich narracji, [in:] Zobaczyć siebie. Polski film dokumentalny przełomu wieków, M. Jazdon, K. Mąka-Malatyńska (eds.), Poznań 2011, pp. 31-49.

Szyłło A., Staś przystapit, “Gazeta Wyborcza” 2014, 8 maja, http://wyborcza.pl/duzyformat/1,127 290,15917294,Stas_przystapil.html [access: 23.06.2018].

${ }^{20}$ In the context of Cuske's film, this topic was taken up by M. Przylipiak, op. cit., s. 45, and K. Mąka-Malatyńska, Dokumentalny autobiografizm, [in:] Historia polskiego filmu dokumentalnego (19452014), M. Hendrykowska (ed.), Poznań 2015, p. 602. 